\title{
AhR-active compounds in sediments of the Haihe and Dagu Rivers, China
}

\author{
Maoyong Song a,b, Qinting Jiang ${ }^{\mathrm{b}}$, Yan Xu ${ }^{\mathrm{b}}$, Hanxia Liu ${ }^{\mathrm{a}}$, \\ Paul K.S. Lam ${ }^{\mathrm{b}}$, Desmond K. O'Toole ${ }^{\mathrm{b}}$, Qinghua Zhang ${ }^{\mathrm{a}}$, \\ John P. Giesy ${ }^{\text {b,c }}$, Guibin Jiang ${ }^{a, *}$
}

${ }^{a}$ State Key Laboratory of Environmental Chemistry and Ecotoxicology, Research Center for Eco-Environmental Sciences, Chinese Academy of Sciences, P.O. Box 2871, Beijing 100085, China

${ }^{\mathrm{b}}$ Research Centre for Coastal Pollution and Conservation, Department of Biology and Chemistry,

City University of Hong Kong, Tat Chee Avenue, Kowloon, Hong Kong

c Department of Zoology, National Food Safety and Toxicology Center, Center for Integrative Toxicology,

Michigan State University, East Lansing, MI 48824, USA

Received 22 June 2005; received in revised form 29 August 2005; accepted 30 August 2005

Available online 2 December 2005

\begin{abstract}
Total concentrations of compounds that can cause activation of the aryl hydrocarbon receptor (AhR) in extracts of river sediments from various locations in the Haihe and Dagu Rivers, Tianjin, China were determined by use of the in vitro H4IIE-luc cell line. AhR-active compounds were isolated from sediments by Soxhlet extraction, and the crude extracts were fractionated using a Florisil column into three Fractions. The response of samples was compared to the TCDD standard and expressed as 2,3,7,8-tetrachlorodibenzo- $p$-dioxin (TCDD) equivalents (TCDD-EQs). Significant dioxin-like activity was observed in each sample. The TCDD-EQs in crude extracts of sediments (SCEs), as determined with the bioassay were 2-4 times greater than the sum of the TCDD-EQs of the eluent from fractions separated with a Florisil column. The results also showed that Fractions 2 and 3 contained most of the AhR-mediated activity. The results obtained by using the bioassay were compared with those of previous measurements of the concentrations of polychlorinated dibenzo-p-dioxins (PCDDs) and polychlorinated dibenzofurans (PCDFs) and the structurally-similar AhR-active polychlorinated biphenyls (PCBs). It was determined that sediments from the Dagu River contained greater concentrations of TCDD-EQ than did sediments from the Haihe River except at Jingangqiao (location R3), which is associated with industrial activities in the adjacent densely populated area. The concentrations of TCDD-EQs, based on the $\mathrm{EC}_{20}$ and the relative potency ranges, of SCEs ranged from 330 to 930 and 1200 to $13900 \mathrm{pg}$ TCDD-EQ g ${ }^{-1}$ dry wt in Haihe and Dagu Rivers, respectively.

(c) 2005 Elsevier Ltd. All rights reserved.
\end{abstract}

Keywords: H4IIE-luc; Dioxin; PCBs

\footnotetext{
* Corresponding author. Tel.: +86106284 9334; fax: +8610 62923563.

E-mail address: gbjiang@mail.recees.ac.cn (G. Jiang).
}

\section{Introduction}

A large number of chemicals can interact with the aryl hydrocarbon receptor $(\mathrm{AhR})$ such that a cascade 
of biochemical effects occur that ultimately can result in a wide range of adverse effects in wildlife (Giesy and Kannan, 1998). AhR-active compounds, sometimes referred to as dioxin-like compounds because they are structurally similar to the prototypical compound, 2,3, 7,8-tetrachlorodibenzo- $p$-dioxin (TCDD), include many subclasses of chemicals, many of which are persistent and bioaccumulative, diaromatic hydrocarbons such as polychlorinated dibenzo-p-dioxins (PCDDs), polychlorinated dibenzofurans (PCDFs), polychlorinated biphenyls (PCBs) and polychlorinated naphthalenes (PCNs), as well as polycyclic aromatic hydrocarbons (PAHs) (Giesy et al., 1994a; Villeneuve et al., 2002). There are literally thousands of chemicals that exhibit AhR-mediated activity (Giesy et al., 1994b; Murk et al., 1996) including heterocyclic oxygen- and sulfur-containing compounds for which authentic standards are not available. The PCDD/PCDFs and structurally-similar compounds constitute a group of lipophilic, persistent, ubiquitous, and bioaccumulative environmental chemicals exhibiting a broad spectrum of biological effects (Giesy and Kannan, 1998; Behnisch et al., 2003), some of which include hepatotoxicity, induction of certain types of cancer, thymic atrophy, immunotoxicity, wasting syndrome, reproductive toxicity, and induction of monooxygenase enzymes or porphyria (Poland and Knutson, 1982; Brouwer et al., 1995; Denison and Heath-Pagliuso, 1998; Denison et al., 1998; Van den Berg et al., 1998).

The bioaccumulation of AhR-active compounds in humans and their biomagnification in the food chain (Giesy et al., 1994b; Berggrena et al., 1999) is worthy of further study but convenient methods of determination are required. Until about ten years ago, a prohibitively expensive method, namely high-resolution gas chromatography/high-resolution mass spectrometry (HRGC/HRMS), was the only option and became the "gold standard" for detecting dioxin-like compounds (Schoeters et al., 2004). However for environmental samples, without prior knowledge of the compounds that might be present or authentic standards for all of the known AhR-active compounds, and the fact that the compounds can interact with one another it is difficult to predict the total AhR-mediated activity of an environmental sample. The uncertainty is exacerbated by the fact that relative potency (REP) values or toxic equivalency factors (TEFs) are not available for all of the classes or compounds that may be present in environmental matrices (Van den Berg et al., 1998). The use of bioanalytical methods can provide a comprehensive measure of total AhR-mediated activity and its associated risk (Behnisch et al., 2003). A bioassay method has the advantage of integrating the toxic potency of all the compounds in a sample and of being more rapid and inexpensive when many samples need to be assessed (Schirmer et al., 2004).
The bioassay used in this study is based on the ability to activate the AhR-signal transduction pathway (Hilscherova et al., 2000). The H4IIE-luciferase induction assay is an in vitro technique that offers a more cost effective alternative for the identification of AhR-active compounds (Sanderson et al., 1996). The assay is also referred to as the chemical activated luciferase gene expression (CALUX) system based on rat hepatoma cells stably transfected with an AhR-controlled luciferase reporter gene construct (Murk et al., 1996; Sanderson et al., 1996; Giesy et al., 2002). Luciferase induction potential is assessed by comparing the response to the sample with the response to TCDD (Villeneuve et al., 2000). This bioanalytical assay has been used to detect and determine the toxicity of complex mixtures of dioxin-like compounds in extracts of environmental samples such as soil, water, food and biota (Villeneuve et al., 2000; Behnisch et al., 2001), but is particularly useful for the rapid screening of total concentrations of TCDD-EQ in sediments (Khim et al., 2001; Hilscherova et al., 2001). The H4IIE-luc cell line was developed at Michigan State University (Sanderson et al., 1996). The transfected cells contain an AhR element which controls the luciferase reporter gene. Binding of compounds to the AhR leads to transcription of the luciferase gene and the production of the luciferase enzyme.

While the AhR-active compounds have been found in many parts of the world as persistent environmental contaminants, due to a general lack of instrumentation and trained personnel, until recently this class of compounds was poorly characterized in much of the People's Republic of China (UNEP-Chemicals, 2002). The Haihe River, the largest water system in northern China, flows through the Tianjin area. The Tianjin region has a long history as an industrial city with a population of 9.2 million. Industrial and domestic waste waters from the city and agricultural effluent discharge into the Haihe River which carries the water to the Bohai Sea at Tanggu influx (Yuan et al., 2004). The Dagu River is another very important channel into which wastewater from domestic sources and from industries in Tianjin is discharged to be finally emptied into the Bohai Sea. Some toxic compounds, such as organochlorine pesticides (OCPs), xeno-estrogens (including 4-tert-octylphenol, 4-nonylphenol and bisphenol A) and mercury, have been reported in the previously studies in this area (Jin et al., 2004; Shi et al., 2005; Wan et al., 2005; Yang et al., 2005). However, few data are available to indicate the level of contamination of dioxin-like compounds in these rivers. Sediments are the eventual sink for dioxin-like compounds in the aquatic environment (Berggrena et al., 1999; Hurst et al., 2004), so eleven sites (Fig. 1) were selected along the Haihe River and the Dagu River for sediment sampling and testing. This paper presents the results of using the H4IIE-luc bioassay to determine total concentrations of TCDD-EQ in surficial sediments. 


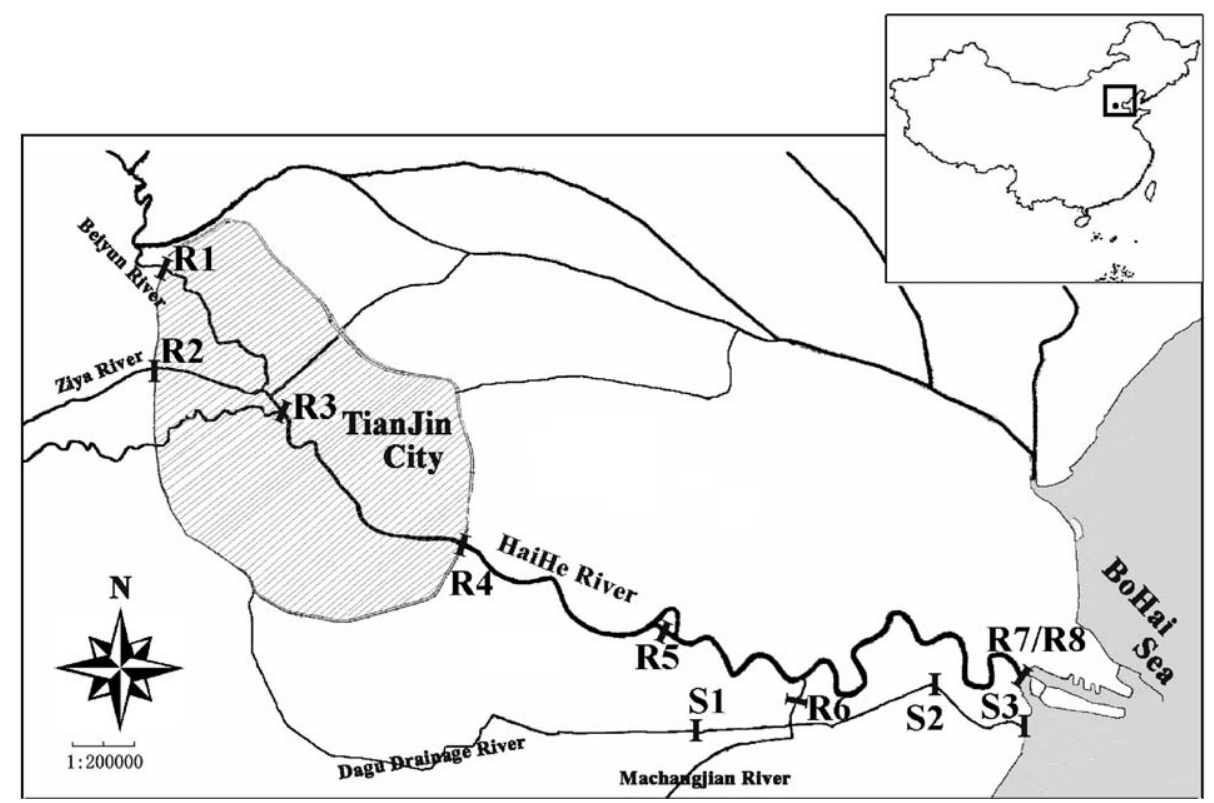

Fig. 1. Map of the sampling locations in Haihe River and Dagu River, Tianjin, China.

\section{Materials and methods}

\subsection{Sample collection}

Sediment samples were collected from 11 sites along the Haihe and Dagu River on November 15-16, 2003 (Fig. 1). Sampling sites R1 and R2 are in Beiyun River and Ziya River, which are the two main branches of Haihe River that converge in Tianjin. The R3 sampling site lies in an urban district and is an important crossing point of several branches of the Haihe River. Site R4 is the location where the Haihe River flows out from Tianjin. Sites R5 and R7 are located at the two gates of the Haihe River. Site R8 is in the estuary of the Haihe River. Dagu River and Machangian River are important drainage rivers in Tianjin. The sampling site R6 is in the Machangjian River just before it pours into the middle reaches of the Haihe River, and sampling sites S1, S2 and S3 are in the Dagu River.

Samples of sediments $(<10 \mathrm{~cm}$ depth) were collected with a stainless steel grab and then placed into hexanerinsed glass jars with aluminum foil covering. All sediment samples were immediately transferred to the laboratory and kept at $-20^{\circ} \mathrm{C}$ in the refrigerator until extraction.

\subsection{Total sediment extract and fractionation}

Sediment extraction and cleanup was performed before the samples were analyzed using the H4IIE-luc bioassay following previously published methods (Khim et al., 2001; Koh et al., 2004). The samples were freeze dried, homogenized using a blender with stainless steel blades, and passed through a $63-\mu \mathrm{m}$ sieve. Five gram of the freeze-dried sediment was mixed with $10 \mathrm{~g}$ of silica (Merck, silica gel 60, column chromatography), and $15 \mathrm{~g}$ of anhydrous sodium sulphate $\left(\mathrm{Na}_{2} \mathrm{SO}_{4}\right)$ to remove residual moisture. The sediment was then refluxed with a mixture of $300 \mathrm{ml}$ dichloromethane (DCM) and hexane (1:1) for $16 \mathrm{~h}$ in a Soxhlet apparatus. Acid-activated copper powder was used to remove the sulfur in the sediment during extraction. The blank consisted of the same amount of anhydrous $\mathrm{Na}_{2} \mathrm{SO}_{4}$, silica and copper powder only. After extraction, the solvent-soluble material was back extracted into hexane by rinsing the solvent three times with $15 \mathrm{ml}$ hexane in a separating funnel. The extract was rotary evaporated $\left(\sim 40^{\circ} \mathrm{C}\right)$ and transferred to $1 \mathrm{ml} n$-hexane.

The concentrated sediment extract was further fractionated into three fractions (Hilscherova et al., 2001) through a column that contained $10 \mathrm{~g}$ of activated Florisil (60-100 mesh size; Sigma, St. Louis, Mo, USA). After the extract was added to the column, hexane was added until $100 \mathrm{ml}$ of hexane was eluted to obtain Fraction 1 that contained the PCBs and a portion of the PCDD/PCDFs. A mixture of hexane containing 20\% DCM was next used to elute organochlorine (OC) compounds, PAHs, alkylphenolethoxylates and the remaining PCDD/PCDFs to obtain Fraction 2. Fraction 3 was eluted with $100 \mathrm{ml} \mathrm{DCM}$ and contained the most 
polar compounds, such as the breakdown products of steroids. The H4IIE-luc bioassay was performed on each fraction to calculate the contribution that each of these Fractions made to the overall AhR-mediated activity.

\subsection{H4IIE-luc assay}

The H4IIE cells were cultured aseptically in Dulbecco's Modified Medium (Sigma) with 10\% fetal bovine serum (FBS, Logan, UT). Cells were continuously cultured in $100 \mathrm{~mm}$ tissue culture plates (Cambridge, MA) under standard conditions $\left(37^{\circ} \mathrm{C}, 5 \% \mathrm{CO}_{2}\right)$ until $80-90 \%$ cell confluence. Cells were then collected and diluted to a final concentration of about 60000 cells $\mathrm{ml}^{-1}$ with culture medium. To conduct the test $250 \mu \mathrm{l}$ of cell suspension was added to each well (about 15000 cells) of a 96-well plate using an Eppendorf repeat pipettor and incubated as before for $24 \mathrm{~h}$ until the cell layer reached $60-80 \%$ confluence when the medium was replaced with $250 \mu \mathrm{l}$ of dextran/charcoal-stripped fetal bovine serum (Hyclone, Logan, UT) medium containing the test material. At least six concentrations of the calibration standard or extract were tested and each exposure was in triplicate. Blank controls and 2,3,7,8TCDD calibration standards $\left(0.1-30 \mathrm{pg} \mathrm{well}^{-1}\right)$ were included on each well plate followed by incubation for 3 days. After addition of $100 \mu 1$ luciferase assay reagent (Luclite Luciferase Assay Kit; Packard BioScience, Meriden, CT), the luciferase activity was determined using an automated luminometer (BMG LABTECH, PolarStar, Durham, NC). For calculation of TCDD equivalent (TCDD-EQ) values the luciferase activity of extract was interpolated using the TCDD standard curve (Fig. 2(A)), and was based on the fragmentary parallel slopes (Villeneuve et al., 2000).

\subsection{TCDD-EQ calculation}

Because complete dose-response curves reached the maximal induction caused by the TCDD standard $\left(\mathrm{TCDD}_{\max }\right)$ and there were significant differences between estimates made based on the $\mathrm{EC}_{50}$ and the $\mathrm{EC}_{20}$ (Fig. 3), activity was calculated based on the $\mathrm{EC}_{20}$ values using REP range and the point of departure (Moore and Caux, 1997; Oris and Bailer, 1997; Putzrath, 1997; Villeneuve et al., 2000). When this method was applied, the H4IIE cells were found to be sufficiently sensitive to determine TCDD-EQs in sediment extracts. Sediment extract equivalents as little as $0.01 \mu 1 \mathrm{well}^{-1}$ (extract from $0.5 \mathrm{mg}$ sediment) were sufficient to induce a significant response relative to the solvent control. When mass of sediment extract equivalents used in the assay was increased, a significant cytotoxicity towards the H4IIE cells was observed at a level of $0.83 \mu 1 \mathrm{well}^{-1}$ or $2.5 \mu 1 \mathrm{well}^{-1}$ (SCE and Fraction 1; Fig. 2(B)). Otherwise, complete dose-response curves were obtained with
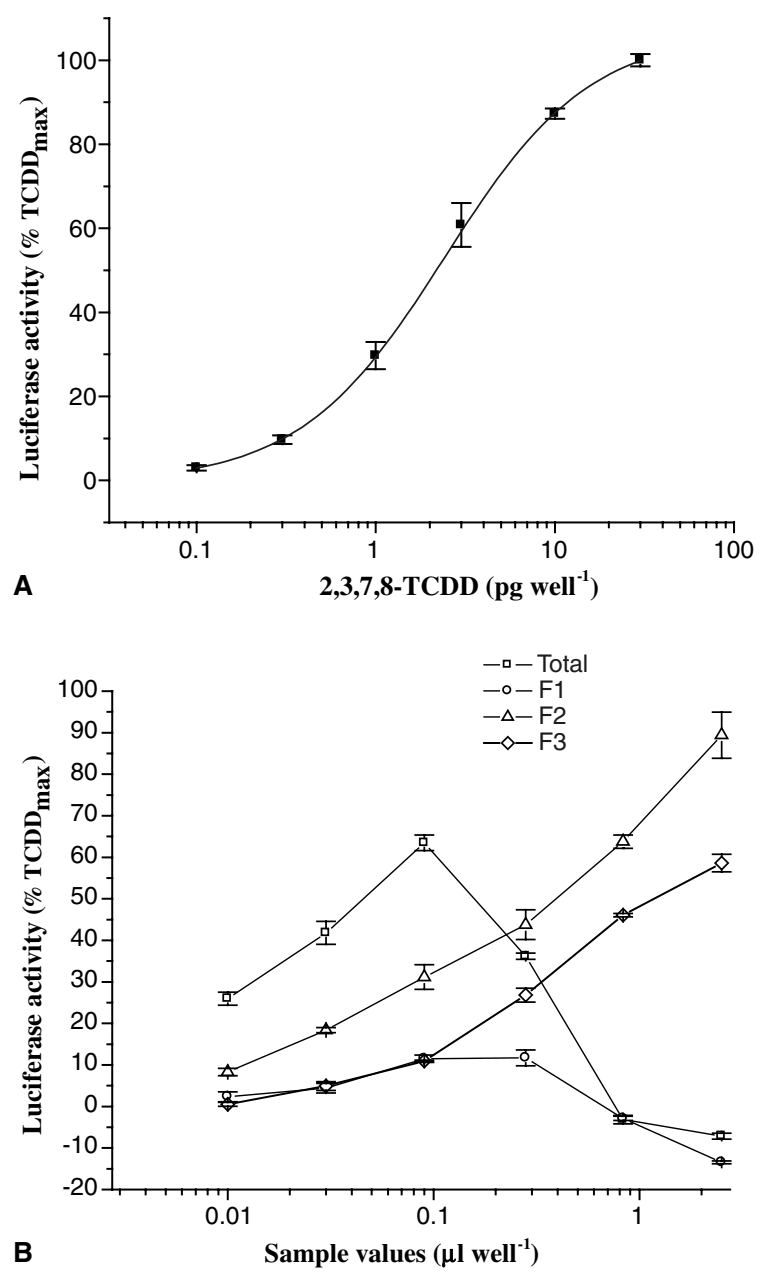

Fig. 2. Does-response curves for the induction of luciferase activity in the H4IIE-luc assay. (A) H4IIE-luc activity induced by 2,3,7,8-TCDD. (B) H4IIE-luc activity induced by sediment crude extract (Total) and fractions of SCE separated by Florisil column chromatography (F1: Fraction 1, F2: Fraction 2 and F3: Fraction 3). Luciferase induction is expressed in terms of the percentage of luciferase activity relative to that of $30 \mathrm{pg}$ well $^{-1} 2,3,7,8$-TCDD $\left(\mathrm{TCDD}_{\text {max }}\right)$. Values represent the mean \pm $\mathrm{SD} ; n=3$.

most of the Fraction 2 and Fraction 3 sediment extracts (F2 and F3; Fig. 2(B)).

\subsection{Cytotoxicity to H4IIE-luc cells}

In addition to the H4IIE-luc assay the compounds of interest and environmental mixtures were tested for cytotoxicity towards the H4IIE-luc cells using a LIVE/ DEAD $^{\circledR}$ Viability/Cytotoxicity Kit (L-3224) (Molecular Probes, Invitrogen, Eugene, OR). Live cells were determined with the polyanionic dye calcein, which is retained within live cells, and produces an intense 


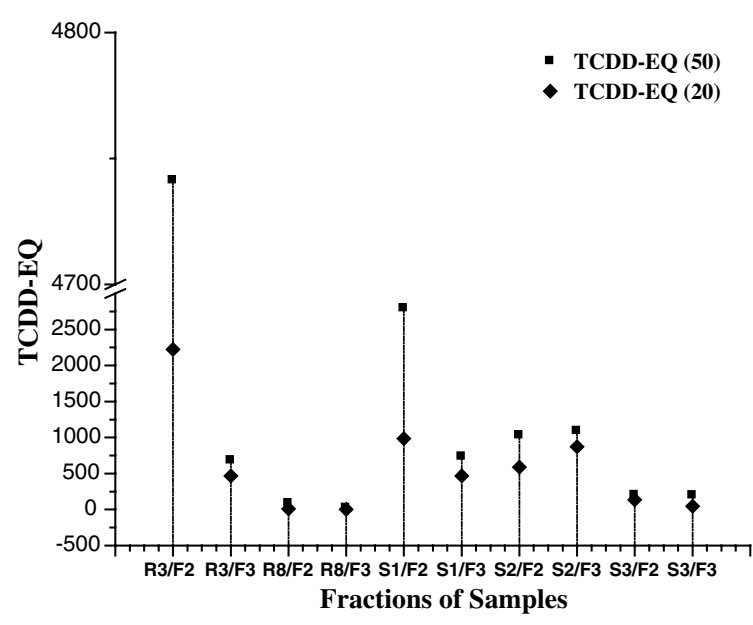

Fig. 3. Comparison between TCDD-EQs in the H4IIE-luc assay calculated based EC20 and EC50 values.

uniform green fluorescence under UV. Dead cells were identified by use of ethidium homodimer-1 (EthD-1) dye, which binds to occult DNA when cells are lysed, and produces a bright red fluorescence under UV. Only dose ranges of sediment extracts that did not cause cytotoxic effects were used in the subsequent bioassay.

\subsection{Chemical analysis}

Sediments collected from the same locations on July 7-12, 2003 had been previously analyzed for AhR-active PCDD/PCDFs and PCBs by HRGC/HRMS (Zhang, 2004). Ten PCDDs, seven PCDFs and twelve dioxinlike PCBs in the sediment samples were determined. The analysis used H4IIE-luc-specific TEFs to calculate TEQ (e.g. Sanderson et al., 1996; Khim et al., 2001; Koh et al., 2004) based on concentrations of PCDD, PCDF and AhR-active PCB congeners to all the dioxin-like activity in the sediment samples.

\section{Results and discussion}

\subsection{H4IIE-luc assay}

Concentrations of TCDD-EQs were determined by comparing the dose-response relationship of the extract of a known mass of sediment to a TCDD standard curve (Villeneuve et al., 2000). Mean values of luciferase response/TCDD $\mathrm{T}_{\max }$ response measured in three replicate wells were used to generate the dose-response curves. The dose-response curve of TCDD used as a standard in the H4IIE-luc bioassay was sigmoidal in appearance (Fig. 2(A)). Luciferase induction was reproducible with coefficients of variation (CV) less than $15 \%$. The limit of detection (LOD) and $\mathrm{EC}_{50}$ for luciferase induction by TCDD were $0.16 \mathrm{pg} \mathrm{well}^{-1}\left(0.05 \mathrm{fmol} \mathrm{well}^{-1}\right)$ and $2.52 \pm 0.49 \mathrm{pg} \mathrm{well}^{-1}\left(0.80 \pm 0.16 \mathrm{fmol}_{\mathrm{well}}{ }^{-1}\right)$, respectively. Typical results obtained with the H4IIE-luc analysis of sediment extracts and fractions are given (Fig. 2(B)).

\subsection{AhR-mediated activity of crude extracts of sediments}

Eleven SCEs were analyzed at six dilutions. At SCE concentrations greater than $11 \%\left(0.28 \mu\right.$ l extract well $\left.{ }^{-1}\right)$ that were used for screening, all sediment extracts exhibited cytotoxicity towards the H4IIE cells. However, at SCE concentrations from $0.49 \%$ to $3.7 \%(0.01-0.09 \mu \mathrm{l}$ extract well ${ }^{-1}$ ) there were significant responses in the H4IIE cells without any observed cytotoxicity. Response magnitude presented as percentage of the maximum response was observed for a $30 \mathrm{pg} \mathrm{well}^{-1} 2,3,7,8$-TCDD $\left(\% \mathrm{TCDD}_{\max }\right)$ with the greatest value for each sample shown in Fig. 4. The greatest magnitude of activity observed for SCEs was $63.5 \% \mathrm{TCDD}_{\max }$, for location S1. Only two SCEs yielded a response greater than $50 \% \mathrm{TCDD}_{\max }$ (locations $\mathrm{R} 3$ and $\mathrm{S} 1$ ) and one lower than $20 \% \mathrm{TCDD}_{\max }$ (location R7).

The TCDD-EQs, based on the $\mathrm{EC}_{20}$ and the REP ranges of all SCEs, are shown (Table 1). Concentrations of TCDD-EQs in sediments from the Dagu River were greater than those in sediment from the Haihe River, except for one location (Jingangqiao: Location R3).

According to reports on environmental quality in Tianjin, during 2002, the total industrial effluents from the area were $2.2 \times 10^{8} \mathrm{t}$. One municipal sewage treatment plant (STP) effluent (capacity of treatment, $2.6 \times 10^{5} \mathrm{t} \mathrm{d}^{-1}$ ) discharged into the Dagu River and finally entered into the Bohai Sea. The Dagu River and another drainage river have been reported to receive

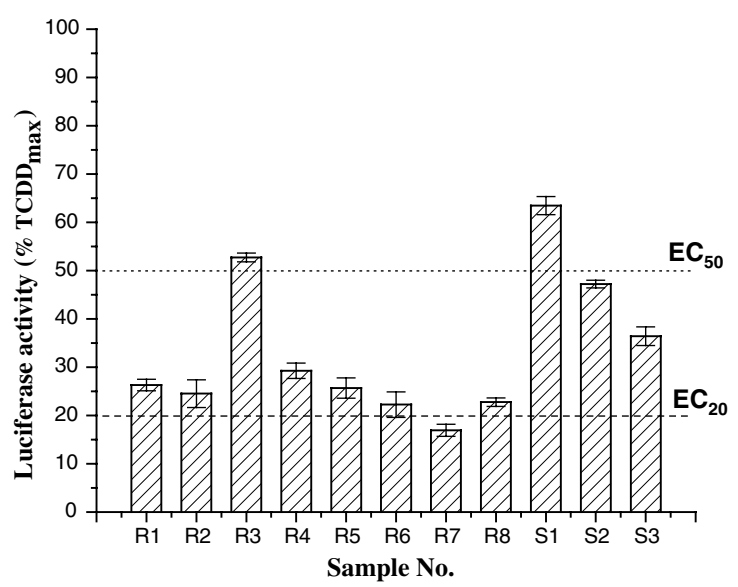

Fig. 4. Maximal luciferase induction in the H4IIE-luc assay elicited by the sediment crude extracts (SCEs). Response magnitude is expressed as percentage of $\mathrm{TCDD}_{\max }$. 
Table 1

TCDD-EQs obtained using H4IIE-luc assays of sediment crude extracts (SCEs)

\begin{tabular}{|c|c|c|c|}
\hline Sampling site code & Sampling site name & Latitude/Longitude & $\begin{array}{l}\text { pg TCDD-EQ g }{ }^{-1} \text { dry wt } \\
\left(\text { REP range }^{\mathrm{a}} \% \mathrm{TCDD}_{\max }\right)\end{array}$ \\
\hline $\mathrm{R} 1$ & Beiyun River & $39^{\circ} 13.673^{\prime} \mathrm{N} 117^{\circ} 06.425^{\prime} \mathrm{E}$ & $693.9(6.5-26.3)$ \\
\hline $\mathrm{R} 2$ & Ziya River & $39^{\circ} 10.523^{\prime} \mathrm{N} 117^{\circ} 05.945^{\prime} \mathrm{E}$ & $501.2(-5.7-24.5)$ \\
\hline R3 & Jingang Bridge & $39^{\circ} 08.918^{\prime} \mathrm{N} 117^{\circ} 11.148^{\prime} \mathrm{E}$ & $6834(11.7-52.4)$ \\
\hline $\mathrm{R} 4$ & Haihe Bridge & $39^{\circ} 04.346^{\prime} \mathrm{N} 117^{\circ} 18.648^{\prime} \mathrm{E}$ & $926.6(11.2-29.2)$ \\
\hline R5 & Erdao Gate & $39^{\circ} 01.341^{\prime} \mathrm{N} 117^{\circ} 26.759^{\prime} \mathrm{E}$ & $679.9(-1.7-25.7)$ \\
\hline R6 & Machangjian River & $38^{\circ} 58.789^{\prime} \mathrm{N} 117^{\circ} 32.909^{\prime} \mathrm{E}$ & $676.6(0.6-22.3)$ \\
\hline R7 & Haihe Gate Front & $38^{\circ} 59.190^{\prime} \mathrm{N} 117^{\circ} 42.773^{\prime} \mathrm{E}$ & $331.7(2.3-16.9)$ \\
\hline $\mathrm{R} 8$ & Haihe Gate Back & $38^{\circ} 59.190^{\prime} \mathrm{N} 117^{\circ} 42.773^{\prime} \mathrm{E}$ & $545.2(3.9-22.8)$ \\
\hline $\mathrm{S} 1$ & Xinzhuangzi River & $38^{\circ} 57.792^{\prime} \mathrm{N} 117^{\circ} 28.745^{\prime} \mathrm{E}$ & $13890(-8.1-63.5)$ \\
\hline $\mathrm{S} 2$ & Mid-Dagu River & $38^{\circ} 58.329^{\prime} \mathrm{N} 117^{\circ} 35.983^{\prime} \mathrm{E}$ & $3798(14.8-47.2)$ \\
\hline S3 & Down-Dagu River & $38^{\circ} 57.817^{\prime} \mathrm{N} 117^{\circ} 41.978^{\prime} \mathrm{E}$ & $1182(5.8-36.4)$ \\
\hline
\end{tabular}

a REP range includes the response of the well where the dilution used is cytotoxic towards the H4IIE-luc cells.

$65 \%$ of the sewage effluent from Tianjin including domestic wastewater (Jin et al., 2004). This is a potential source of TCDD-EQ. The present study is the first investigation using in vitro bioassay of dioxin-like compounds in sediments collected in this area. The results indicate that the dioxin-like activities in SCEs collected in the Tianjin area are similar to previous reports of sediments from UK estuaries (1.1-154 ng TCDD-EQ $\mathrm{g}^{-1}$ dw) (Hurst et al., 2004) and sediment from the Czech River Basin $\left(0.782-22.3\right.$ ng TCDD-EQ g ${ }^{-1} \mathrm{dw}$ ) (Hilscherova et al., 2001).

\subsection{AhR-mediated activity of fractions}

Six dilutions of each of the three Fractions were tested with the H4IIE cell line. Five samples were selected for further analysis. The greatest response of each Fraction of those selected samples is shown (Fig. 5). PCBs and some of the PCDD/PCDFs were eluted in F1, which are non-polar compounds that have relatively great AhR-mediated activity. Due to their small concentrations AhR-active compounds in F1 contributed only a small proportion of the total TCDD-EQs (Table 2). Concentrations of TEQs calculated for sediments based on concentrations of each PCDD/PCDF and coplanar PCB congener and their respective TEF (Van den Berg et al., 1998) for locations S2 and S3, were 285 and $893 \mathrm{pg} \mathrm{TEQ/g} \mathrm{dw,} \mathrm{respectively.} \mathrm{Of} \mathrm{the} \mathrm{three}$ fractions, only F1 caused significant cytotoxicity to H4IIE cells. The range of cytotoxic concentrations was from $11 \%$ to $100 \%\left(0.28-2.5 \mu\right.$ l extract well $\left.{ }^{-1}\right)$. These results indicate that the cytotoxic compounds were non-polar and concentrated in F1. It was unknown whether the cytotoxic compounds could affect the response of H4IIE cells to the PCDD/PCDFs and PCBs in the valid concentration wells.

The greatest induction of luciferase activity was caused by fractions 2 (F2) and 3 (F3) for these five sam-

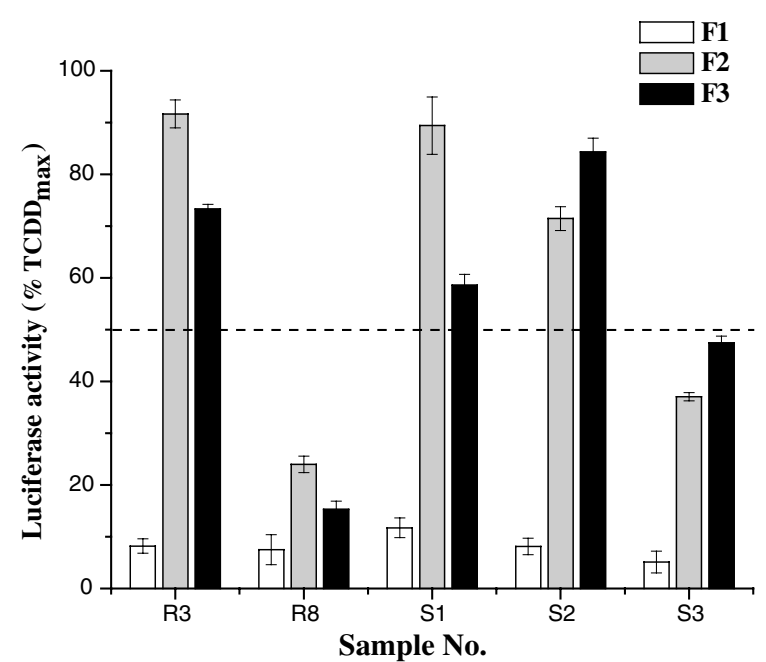

Fig. 5. Maximal luciferase induction in the H4IIE-luc assay elicited by individual fractions separated by Florisil column chromatography (F1: Fraction 1, F2: Fraction 2 and F3: Fraction 3). Response magnitude is expressed as percentage of TCDD $_{\max }$.

ples. The magnitudes of induction were 2- and 12-fold greater than that of $\mathrm{F} 1$ but no samples elicited a response higher than the $\mathrm{TCDD}_{\max }$. F2 contained PAHs, their derivatives, $\mathrm{OC}$ pesticides and a portion of the PCDD/ PCDFs. Some PAHs, such as benzo $(a)$ pyrene (BAP), dibenz $(a, h)$ anthracene (DBA), benzo $(a)$ anthracene (BA), benzo $(k)$ fluoranthene $(\mathrm{BkF}), \quad$ benzo $(b)$ fluoranthene $(\mathrm{BbF})$, chrysene $(\mathrm{Chr})$, and indeno(1,2,3-c,d)pyrene (IdP), are a class of chemicals that can significantly contribute to the induction-TEQs. In the study area, the concentrations of PAHs have been reported to be 800 $1200 \mu \mathrm{g} \mathrm{kg}^{-1}$ soil (Wang et al., 2003). This indicates that the relatively great concentrations of PAHs could be responsible for the AhR-mediated activity in F2. The 
Table 2

Comparison of sediment crude extracts (SCEs) and fractions analyzed by H4IIE-luc assay (TCDD-EQ) and chemical analysis (HRGC-HRMS; TEQ)

\begin{tabular}{|c|c|c|c|c|c|c|}
\hline & \multicolumn{5}{|c|}{ H4IIE-luc-TCDD-EQs } & \multirow{2}{*}{$\begin{array}{l}\text { TEQ } \\
\sum \text { HRGC-HRMS } \\
\sum \text { TEQ PCDD/PCDFs + PCBs }\end{array}$} \\
\hline & SCEs & $\sum F 1+F 2+F 3$ & $\mathrm{~F} 1^{\mathrm{a}}$ & $\mathrm{F} 2$ & $\mathrm{~F} 3$ & \\
\hline R3 & 6834.2 & 5592.6 & 168.3 & 4741.3 & 683.0 & 6.76 \\
\hline $\mathrm{R} 8$ & 545.2 & 187.1 & 79.4 & 84.7 & 23.0 & 19.13 \\
\hline $\mathrm{S} 1$ & 13892.1 & 3718.2 & 190.3 & 2794.4 & 733.5 & 21.93 \\
\hline $\mathrm{S} 2$ & 3797.8 & 2270.3 & 152.7 & 1028.8 & 1088.8 & 284.97 \\
\hline S3 & 1182.5 & 527.2 & 129.4 & 200.5 & 197.3 & 892.59 \\
\hline
\end{tabular}

${ }^{\mathrm{a}}$ The maximal luciferase induction was less than $\mathrm{EC}_{20}$ relative to $\mathrm{TCDD}_{\max }$.

third fraction (F3) also elicited significant AhR-mediated luciferase activity. For some samples (S2 and S3), maximum induction in $\mathrm{F} 3$ was greater than that caused by F2. The chemicals that caused the dioxin-like activities in polar F3 are unknown. The sums of the TCDD-EQs from the fractions were significantly less than the TCDD-EQs for total extract. This may suggest antagonistic interactions among compounds. Furthermore, the Florisil column could have adsorbed some of the compounds that could elicit dioxin-like activity (Hilscherova et al., 2001).

The TCDD-EQs derived by H4IIE-luc bioassay are significantly correlated with TEQs $\left(R^{2}=0.75\right.$, Fig. 6). Concentration of TCDD-EQs estimated by use of the H4IIE-luc assay calculated were greater than the concentration of TEQ predicted from the individual PCDD/PCDF and PCB congeners. The most likely cause of the difference between the two methods of measuring AhR activity in the sediments is the presence of

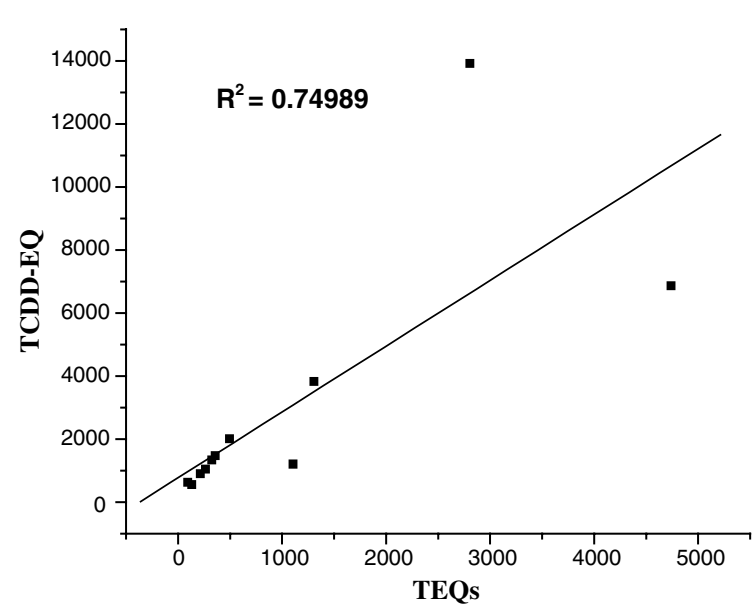

Fig. 6. Relationship between toxic equivalents determined by H4IIE-luc (TCDD-EQH4IIE-luc) and toxic equivalents (TEQs) is the sum of $\mathrm{TEQ}_{\mathrm{PCDD} / \mathrm{PCDF}}+\mathrm{PCBs}$ (based on instrumental analysis and WHO-TEF) and TEQ ${ }_{\mathrm{PAH}}$ (based on H4IIE-luc bioassay).
AhR-active compounds other than those measured in this study. Of those unknown compounds capable of producing dioxin-like responses in the H4IIE-luc assay that may be present in the samples the most likely are the PAHs (Hilscherova et al., 2001; Hurst et al., 2004). The compounds responsible for dioxin-like activity in F3 are unknown. They may include polar compounds that are relatively weak AhR agonists, which may be of either natural or synthetic origin. Recently, some studies have suggested additional types of AhR ligands and inducers with a wide structural variety, some of which could have been present in our sediment samples at concentrations sufficient to cause the observed induction (Denison et al., 1998). Also, studies with marine sediments have documented the presence of unknown AhR-active compounds in the most polar fractions of sediment extracts (Khim et al., 1999).

\section{Conclusions}

In vitro H4IIE-luc bioassay has been shown to be a useful tool for assessing the dioxin-like activity of complex environmental mixtures. The dioxin-like activities in sediments from Haihe River and Dagu River were significant. Most of the AhR-mediated, dioxin-like activity is attributable to the PAHs in F2 and unidentified polar AhR-active compounds in F3. The H4IIE-luc bioassay is a relatively rapid, inexpensive and sensitive method for detecting and screening the occurrence of AhRactive compounds in complex mixtures before the application of the more expensive and time-consuming instrumental analyses. Application of the bioassay to screen environmental matrices in China will allow more effective use of the relatively limited capacity for analyses by HRGC-HRMS. It also can provide much information on the biological effects of complex mixtures that chemical analysis cannot provide. However, the application of the bioassay cannot quantify specific compounds. Some unknown cytotoxic chemicals may affect the results of bioassay so caution must be applied when assessing the risks posed by TCDD-EQs in sedi- 
ment. To provide an estimate of the relative level of contamination, it is reasonable to use bioassays combined with instrumental analytical approaches.

\section{Acknowledgement}

The work described in this article is supported by the Area of Excellence Scheme under the University Grants Committee of the Hong Kong Special Administration Region, China (Project No. AoE/P-04/2004).

\section{References}

Behnisch, P.A., Hosoe, K., Sakai, S.-I., 2001. Combinatorial bio/chemical analysis of dioxin and dioxin-like compounds in waste recycling, feed/food, humans/wildlife and the environment. Environment International 27, 495-519.

Behnisch, P.A., Hosoe, K., Sakai, S.-I., 2003. Brominated dioxin-like compounds: in vitro assessment in comparison to classical dioxin-like compounds and other polyaromatic compounds. Environment International 29, 861-877.

Berggrena, P., Ishaq, R., Zebühr, Y., Näf, C., Bandh, C., Broman, D., 1999. Patterns and levels of organochlorines (DDTs, PCBs, nonortho PCBs and PCDD/Fs) in Male Harbour Porpoises (Phocoena phocoena) from the Baltic Sea, the Kattegat-Skagerrak seas and the west coast of Norway. Marine Pollution Bulletin 38, 1070-1084.

Brouwer, A., Ahlborg, U.G., Van den Berg, M., Birnbaum, L.S., Boersma, E.R., Bosveld, B., Denison, M.S., Gray, L.E., Hagmar, L., Holene, E., Huisman, M., Jacobson, S.W., Jacobson, J.L., Koopman-Esseboom, C., Koppe, J.G., Kulig, B.M., Morse, D.C., Muckle, G., Peterson, R.E., Sauer, P.J.J., Seegal, R.F., Prooije, A.E.S.-V., Touwen, B.C.L., Weisglas-Kuperus, N., Winneke, G., 1995. Functional aspects of development toxicity of polyhalogenated aromatic hydrocarbons in experimental animals and human infants. European Journal of Pharmacology. Molecular Pharmacology Section 293, 1-40.

Denison, M.S., Heath-Pagliuso, S., 1998. The Ah receptor: a regulator of the biochemical and toxicological actions of structurally diverse chemicals. Bulletin of Environmental Contamination and Toxicology 61, 557-568.

Denison, M.S., Phelan, D., Elferink, C.J., 1998. The Ah receptor signal transduction pathway. In: Denison, M.S., Helferich, W.G. (Eds.), Toxicant-Receptor Interactions. Taylor and Francis, Philadelphia, pp. 3-33.

Giesy, J.P., Kannan, K., 1998. Dioxin-like and non-dioxin-like toxic effects of polychlorinated biphenyls (PCBs): implications for risk assessment. Critical Reviews in Toxicology 28, 511-569.

Giesy, J.P., Ludwig, J.P., Tillitt, D.E., 1994a. Dioxins, dibenzofurans, pcbs and colonial, fish-eating water birds. In: Schecter, A. (Ed.), Dioxin and Health. Plenum Press, New York, pp. 254-307.

Giesy, J.P., Ludwig, J.P., Tillitt, D.E., 1994b. Embryo lethality and deformities in colonial, fish-eating, water birds of the Great Lakes region: assessing causality. Environmental Science and Technology 28, 128-135.
Giesy, J.P., Hilscherova, K., Jones, P.D., Kannan, K., Machala, M., 2002. Cell bioassays for detection of aryl hydrocarbon (AhR) and estrogen (ER) mediated activity in environmental samples. Marine Pollution Bulletin 45, 3-16.

Hilscherova, K., Machala, M., Kannan, K., Blankenship, A.L., Giesy, J.P., 2000. Cell bioassays for detection of aryl hydrocarbon (AhR) and estrogen receptor (ER) mediated activity in environmental samples. Environmental Science and Pollution Research 7, 159-171.

Hilscherova, K., Kannan, K., Kang, Y.-S., Holoubek, I., Machala, M., Masunaga, S., Nakanishi, J., Giesy, J.P., 2001. Characterization of dioxin-like activity of sediments from a Czech river basin. Environmental Toxicology and Chemistry 20, 2768-2777.

Hurst, M.R., Balaam, J., Chan-Man, Y.L., Thain, J.E., Thomas, K.V., 2004. Determination of dioxin and dioxinlike compounds in sediments from UK estuaries using a bio-analytical approach: chemical-activated luciferase expression (CALUX) assay. Marine Pollution Bulletin 49, 648-658.

Jin, X.L., Jiang, G.B., Huang, G.L., Liu, J.F., Zhou, Q.F., 2004. Determination of 4-tert-.octylphenol, 4-nonylphenol and bisphenol A in surface waters from the Haihe River in Tianjin by gas chromatography-mass spectrometry with selected ion monitoring. Chemosphere 56, 1113-1119.

Khim, J.S., Villeneuve, D., Kannan, K., Koh, C.H., Giesy, J.P., 1999. Characterization and distribution of trace contaminants in sediment from Masan Bay, Korea. 2. In vitro gene expression assay. Environmental Science and Technology 33, 4206-4211.

Khim, J.S., Lee, K.-T., Villeneuve, D.L., Kannan, K., Giesy, J.P., Koh, C.-H., 2001. In vitro bioassay determination of dioxin-like and estrogenic activity in environmental samples from Ulsan Bay and its vicinity, Korea. Archives of Environmental Contamination and Toxicology 40, 151-160.

Koh, C.H., Khim, J.-S., Kannan, K., Villeneuve, D.L., Senthilkumar, K., Giesy, J.P., 2004. Polychlorinated dibenzo-pdioxins (PCDDs), dibenzofurans (PCDFs), biphenyls (PCBs), and polycyclic aromatic hydrocarbons (PAHs) and 2,3,7,8-TCDD equivalents (TEQs) in sediment from Hyeongsan River, Korea. Environmental Pollution 132, 489-501.

Moore, D.R.J., Caux, P.Y., 1997. Estimating low toxic effects. Environmental Toxicology and Chemistry 16, 794-801.

Murk, A.J., Legler, J., Denison, M.S., Giesy, J.P., van de Guchte, C., Brouwer, A., 1996. Chemical-activated luciferase gene expression (CALUX): a novel in vitro bioassay for Ah receptor active compounds in sediments and pore water. Fundamental and Applied Toxicology 33, 149-160.

Oris, J.T., Bailer, A.J., 1997. Equivalence of concentrationresponse relationships in aquatic toxicology studies: testing and implications for potency estimation. Environmental Toxicology and Chemistry 16, 2204-2209.

Poland, A., Knutson, J.C., 1982. 2,3,7,8-TCDD and related halogenated aromatic hydrocarbons: examination of the mechanism of toxicity. Annual Review of Pharmacology and Toxicology 22, 517-544.

Putzrath, R.M., 1997. Estimating relative potency for receptormediated toxicity: reevaluating the toxic equivalence factor (TEF) model. Regulatory Toxicology and Pharmacology $25,68-78$. 
Sanderson, J.T., Aarts, J.M.M.J.G., Brouwer, A., Forese, K.L., Denison, M.S., Giesy, J.P., 1996. Comparison of Ah receptor-mediated luciferase and ethoxyresorufin $O$-deethylase induction in H4IIE cells: implications for their use as bioanalytical tools for the detection of polyhalogenated aromatic hydrocarbons. Toxicology and Applied Pharmacology 137, 316-325.

Schirmer, K., Dayeh, V.R., Bopp, S., Russold, S., Bols, N.C., 2004. Applying whole water samples to cell bioassays for detecting dioxin-like compounds at contaminated sites. Toxicology 205, 211-221.

Schoeters, G., Goyvaerts, M.P., Ooms, D., Van Cleuvenbergen, R., 2004. The evaluation of dioxin and dioxin-like contaminants in selected food samples obtained from the Belgian market: comparison of TEQ measurements obtained through the CALUX bioassay with congener specific chemical analyses. Chemosphere 54, 1289-1297.

Shi, J.B., Liang, L.N., Jiang, G.B., Jin, X.L., 2005. The speciation and bioavailability of mercury in sediments of Haihe River, China. Environment International 31, 357365.

UNEP-Chemicals, 2002. Regionally based assessment of persistent toxic substances. Central and North East Asia Regional Report, Global Environmental Facility. 125pp.

Van den Berg, M., Birnbaum, L., Bosveld, A.T., Brunstrom, B., Cook, P., Feeley, M., Giesy, J.P., Hanberg, A., Hasegawa, R., Kennedy, S.W., Kubiak, T., Larsen, J.C., van Leeuwen, F.X., Liem, A.K., Nolt, C., Peterson, R.E., Poellinger, L., Safe, S., Schrenk, D., Tillitt, D., Tysklind, M., Younes, M., Waern, F., Zacharewski, T., 1998. Toxic equivalency factors
(TEFs) for PCBs, PCDDs for humans and wildlife. Environmental Health Perspectives 106, 775-779.

Villeneuve, D.L., Blankenship, A.L., Giesy, J.P., 2000. Derivation and application of relative potency estimates based on in vitro bioassay results. Environmental Toxicology and Chemistry 19, 2835-2843.

Villeneuve, D.L., Khim, J.S., Kannan, K., Giesy, J.P., 2002. Relative potencies of individual polycyclic aromatic hydrocarbons to induce dioxin like and estrogenic responses in three cell lines. Environmental Toxicology 17, 128-137.

Wan, Y., Hu, J.Y., Liu, J.L., An, W., Tao, S., Jia, Z.B., 2005. Fate of DDT-related compounds in Bohai Bay and its adjacent Haihe Basin, North China. Marin Pollution Bulletin 50, 439-445.

Wang, X.J., Zheng, Y., Liu, R.M., Li, B.G., Cao, J., Tao, S., 2003. Kriging and PAH pollution assessment in the topsoil of Tianjin area. Bulletin of Environmental Contamination and Toxicology 71, 189-195.

Yang, R.Q., Lv, A.H., Shi, J.B., Jiang, G.B., 2005. The levels and distribution of organochlorine pesticides (OCPs) in sediments from the Haihe River, China. Chemosphere 61, 347-354.

Yuan, C., Jiang, G., Liang, L., Xin, X., Shi, J., 2004. Sequential extraction of some heavy metals in Haihe River sediments, People's Republic of China. Bulletin of Environmental Contamination and Toxicology 73, 59-66.

Zhang, Q.H., 2004. Study on characteristics of dioxin-like compounds in Taihu Lake and Haihe River Basin in Tianjin. Ph.D. thesis, The Chinese Academy of Sciences, Beijing, China, p. 87-104. 